\title{
PENERAPAN GAYA INDIS PADA PERANCANGAN INTERIOR LOUNGE \& BAR THE HERMITAGE, A TRIBUTE PORTFOLIO HOTEL, JAKARTA
}

\author{
Irvani Anwar ${ }^{1}$, Stephanus Dwiyanto ${ }^{2}$, Sri Sulistyo Purnomo ${ }^{3}$ \\ 1,2,3Prodi Desain Interior, Fakultas Seni Rupa dan Desain, Universitas Tarumanagara, Jakarta \\ ${ }^{1}$ Irvani.615170026@stu.untar.ac.id, ${ }^{2}$ Stephanusd@fsrd.untar.ac.id, ${ }^{3}$ Sulistyopurnomo@fsrd.untar.ac.id
}

\begin{abstract}
Abstrak - Pada masa penjajahan Belanda, Indonesia mendapat Pengaruh Occidental(Barat) banyak diterapkan pada berbagi segi kehidupan termasuk dalam tata kota dan bangunan. Bangunan - bangunan tersebut adalah salah satu bukti jejak kolonialisme Belanda pada masa lampau. Banyak bangunan - bangunan tersebut yang masih di rawat utuh dan ada juga yang di tinggali, serta dijadikan tempat wisata atau tempat kuliner seperti hotel dan restoran. Namun seiringnya waktu, perkembangan zaman modernisasi membuat bangunan - bangunan kolonial ini menjadi sedikit dan banyak juga yang merubah gaya bangunan serta interior sehingga identitas dan sejarah yang terdapat pada bangunan tersebut terlupakan. Penulisan Jurnal ini menggunakan metode analisis deskriptif kualitatif dengan pendekatan tipologi arsitektur yang bertujuan untuk mengetahui bagaimana penerapan gaya Indis baik dari suasana, elemen pembentuk ruang yang ditonjolkan pada interior Lounge The Hermitage, A Tribute Portfolio Hotel, Jakarta apakah penggunaan gaya Indis sesuai dengan karakteristik bangunan yang didirikan pada tahun 1923. Hasil analisis penelitian menunjukan bahwa perancangan interior Lounge The Hermitage, A Tribute Portfolio Hotel, Jakarta sudah menerapkan gaya indis yang sesuai dengan karakteristik bangunan arsitektur kolonial.
\end{abstract}

Kata Kunci : Arsitektur, Gaya Indis, Interior, Kolonial, Lounge.

\section{PENDAHULUAN}

Selama 350 tahun dibawah penjajahan Belanda, tentu saja membuat negara ini terkontaminasi oleh budaya-budaya yang dibawa oleh para penjajah, salah satunya adalah gaya arsitektur, yang sampai saat ini masih banyak bangunan-bangunan tua itu yang berdiri tegak. Pada masa penjajahan Belanda, Indonesia mendapat Pengaruh Occidental(Barat) banyak diterapkan pada berbagi segi kehidupan termasuk dalam tata kota dan bangunan.

$$
\text { Menurut Sumalyo (1995). }
$$

Kebudayaan Belanda tidak saja memengaruhi kehidupan masyarakat
Indonesia saja, tetapi juga, cara berpikir para arsitek Belanda, ketika menerapkan konsep-konsep lokal / tradisional pada bangunan-bangunan rancanganya. Budaya Kolonial di Indonesia adalah fenomena budaya yang unik (percampuran budaya antara penjajah dan budaya Indonesia), dan tidak terdapat dilain tempat, termasuk negara-negara bekas koloni lainnya (Sumalyo,1995). Keunikan bangunan bangunan tersebut dapat dilihat pada bentuk - bentuk bangunan peninggalan Kolonial Belanda, yang menurut hasil identifikasi dan analisis Handinoto 
(2010), gaya arsitektur bangunan zaman itu, terbagi atas tiga gaya arsitektur, yaitu: (1) Indische Empire Style; (2) gaya "Arsitektur Transisi; (3) gaya "Indo-Eropa".

Bangunan - bangunan tersebut adalah salah satu bukti jejak kolonialisme Belanda pada masa lampau. Banyak bangunan bangunan tersebut yang masih di rawat utuh dan ada juga yang di tinggali, serta dijadikan tempat wisata atau tempat kuliner seperti hotel atau restoran.

Perkembangan kota modern memiliki karakteristik yang diantaranya adalah tingkat mobilitas kegiatan kegiatan masyarakat dalam berbagai bidang. Kegiatan perdagangan/bisnis, perkantoran, industri, dan sebagainya; telah membawa masyarakat terjebak dalam rutinitas yang relatif sama dari waktu ke waktu dan cenderung monoton. Oleh karena itu mereka membutuhkan suatu tempat yang dapat memfasilitasi mereka untuk bersantai diantara waktuwaktu senggang yang dimilikinya. Ruang interaksi yang semakin mengecil, serta adanya dorongan yang menginginkan suasana yang baru ditengah padatnya aktifitas untuk merileksasikan diri, sehingga mendorong perpindahan ruang interaksi dari sebuah ruang kerja atau hunian ke tempat-tempat publik. Dengan perkembangan jaman yang semakin modern, kota Jakarta merupakan Ibu kota dimana para pengunjung baik domestik maupun internasional berdatangan sehingga mulai mengikuti pola hidup warga negara asing. Salah satu tempat yang paling diminati sekarang khususnya untuk generasi muda yaitu lounge $\&$ bar yang dimana mereka dapat menikmati beberapa minuman seperti kopi, beer, cocktail dan lain-lain.

Konsep desain interior yang unik pada lounge dan bar sangat mempengaruhi pembeli yang akan datang dan agar tetap kembali lagi ke lounge dan bar tersebut bukan hanya menampilkan sebuah ruang dengan suasana baru tetapi juga menghadirkan kenyamanan yang berbeda, dimana kenyamanan dalam suatu ruang adalah hal terpenting dalam desain. Desain yang berhasil adalah desain yang membuat ruang itu nyaman luar dan dalamnya, sedangkan kenyamanan adalah sebuah perasaan dimana pelanggan atau konsumen berada di titik kepuasan, dalam konsep interior unik sebuah kenyamanan dihadirkan dengan suasana berbeda.

The Hermitage, A Tribute Portfolio, Jakarta merupakan hotel butik berbintang lima yang memiliki Lounge \& Bar. Dulunya 
Fakultas Seni Rupa dan Desain - Universitas Tarumanagara

Irvani Anwar, Stephanus Dwiyanto, Sri Sulistyo Purnomo; Halaman 40-49

gedung ini merupakan kantor telekomunikasi Hindia Belanda yang biasa disebut telefoon gebouw. Gedung ini dibangun pada tahun 1923. Setelah itu, gedung ini pernah mengalami beberapa kali alih fungsi. Pada masa pergerakan, yaitu antara 1945-1950, bangunan bekas telefoon gebouw dijadikan sebagai kantor Badan Pekerja Komite Nasional Indonesia Pusat (KNIP). Kemudian menjadi Departemen Pendidikan dan Pengajaran pada tahun 1950. Lalu, beralih fungsi menjadi kantor Ditjen Kebudayaan Departemen Pendidikan dan Kebudayaan dari tahun 1968 hingga tahun 1996. Kemudian pada tahun 1999, bangunan ini sempat beralih fungsi menjadi ruang kuliah oleh Universitas Bung Karno (UBK). Usai ditinggalkan UBK, gedung ini menjadi kosong dan malah tidak terawat lagi. Kemudian sejak tahun 2008, bangunan lawas diambil alih oleh The Hermitage, dan direnovasi untuk dijadikan hotel dengan tetap mempertahankan nuansa kolonialnya. Di bagian dibangun gedung baru menjulang untuk kamar hotel, sedangkan bagian depannya masih asli. Pada 5 Juni 2014, bangunan kuno ini resmi menjadi hotel mewah bernuansa kolonial dengan nama resminya The Hermitage Hotel. Dari bangunan bersejarah tersebut, terlihat mengandung tipologi arsitektur kolonialisasi dan perancangan ini menerapkan gaya Indis pada interior yang spesifik pada periode kolonisasi saat bangunan ini di bangun.

Namun seiringnya waktu, perkembangan zaman modernisasi membuat bangunan - bangunan kolonial ini menjadi sedikit dan banyak juga yang merubah gaya bangunan serta interior sehingga identitas dan sejarah yang terdapat pada bangunan tersebut terlupakan. Tetapi hal tersebut yang membuat bangunan - bangunan bersejarah ini menjadi salah satu daya tarik bagi para pengunjung. Oleh karena itu pada perancangan ini perancang menerapkan gaya Indis untuk mempertahankan citra bangunan hotel terutama pada bagian interior yang terlihat pada Lounge \& Bar The Hermitage, A Tribute Portfolio Hotel, Jakarta.

Penelitian ini bertujuan untuk mengetahui mengenai penerapan gaya Indis yang terdapat pada interior Lounge \& Bar The Hermitage, A Tribute Portoolio Hotel, Jakarta apakah sesuai dengan langgam/gaya pada tahun dimana tempat ini didirikan. 


\section{METODOLOGI PENELITIAN}

Metode yang digunakan dalam penelitian ini adalah metode analisa deskriptif kualitatif dengan pendekatan tipolog arsitektur pada Lounge \& Bar The Hermitage, A Tribute Portfolio Hotel, Jakarta yang menggunakan data Literatur dan analisis visual untuk mengidentifikasikan bangunan berdasarkan langgam/gaya, lalu menyesuaikan dengan teori yang berkaitan dengan tipologi wajah bangunan interior, dan kemudian mengidentifikasi, menganalisa detail dari setiap elemen wajah arsitektur interior (fasad bangunan, atap, dinding, lantai) dan ditipologikan berdasarkan langgam/gaya bangunanya.

Metode pengumpulan data yang dilakukan yaitu menggunakan metode arsip dengan :

1. Studi pustaka, peneliti mengamati data

- data teori yang dapat digunakan sebagai landasan teori dalam objek perancangan, seperti data literatur mengenai hotel, yang diperoleh dari buku - buku pendukung mengenai hotel, media massa, dan laporan karya desain mengenai hotel.

2. Metode dokumentasi, teknik pengumpulan data untuk memperoleh sumber data melalui gambar - gambar maupun pemotretan. Hal ini dapat diperoleh melalui internet seperti foto foto dokumentasi yang berkaitan dengan hotel.

Pada metode pengolahan data, data yang diperoleh dari studi banding, dan literatur dikumpulkan. Setelah itu dilakukan penyeleksian data yang memiliki hubungan dengan perancangan seperti elemen pembentuk ruang, sistem interior, struktur, dan data eksisting. Data - data yang telah terseleksi kemudian diinventaris. Kemudian, data - data tersebut akan dianalisis dari beberapa aspek interior yang digunakan sebagai acuan dalam penyusunan program tabel kebutuhan dalam suatu perancangan interior (programming), pembuatan konsep, dan aplikasi konsep dalam perancangan interior.

Jadi dalam penelitian ini, hasil analisis berupa sebuah deskripsi tentang perwujudan gaya Indis pada arsitektur colonial serta fungsi ruang, elemen pembentuk ruang dam pada restoran yang diteliti berdasarkan pada teori- teori yang sudah ada mengenai gaya kolonial dan berbagai gaya desain lain yang mempengaruhinya. 


\section{HASIL DAN PEMBAHASAN}

\section{A. Arsitektural Bangunan}

Ciri arsitektural pada masa kolonial adalah sebagai berikut :

- Konsep layout secara keseluruhan tidak simetris, hal ini sesuai dengan era yang berkembang saat itu yaitu masa arsitektur kolonial modern (1920-1940). Penentuan pola layout bukan karena pertimbangan faktor simetris, tapi lebih kepada kebutuhan penghuni terhadap ruang-ruang.

- Arsitektur bangunan bergaya IndoEropa yang berkembang pada tahun 1920 - 1930 diarahkan pada bangunan yang memiliki bentuk campuran arsitektur Nusantara dan arsitektur modern disesuaikan iklim, bahan bangunan dan teknologi yang berkembang pada saat itu (Handinoto 2010:86).

- Ciri Arsitektural Kolonial adalah tampilan muka rumah Belanda eksterior atau fasad yang cenderung simetris, meski ada juga beberapa rumah Belanda yang mengaplikasikan fasad asimetris tersendiri dan arsitektural Kolonial biasanya mempunyai dinding yang cukup tebal.

\section{DENAH}

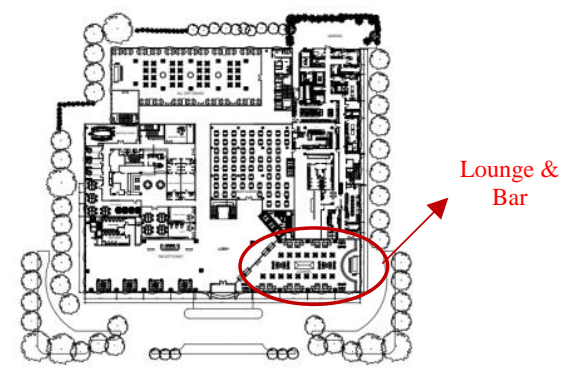

Gambar 1. Layout The Hermitage, A Tribute Portfolio Hotel, Jakarta (Sumber : Irvani, 2020)

Lounge \& Bar pada The Hermitage, A Tribute Portfolio Hotel, Jakarta ini terdiri dari beberapa ruangan yang memiliki bukaan pintu. Denah Lounge \& Bar pada The Hermitage, A Tribute Portfolio Hotel, Jakarta memiliki bentuk geometris yang ramping memanjang ke belakang, Lounge \& Bar ini juga memiliki jendela yang memberikan pencahayaan baik pada pagi dan siang hari.

\section{INTERIOR LOUNGE \& BAR}

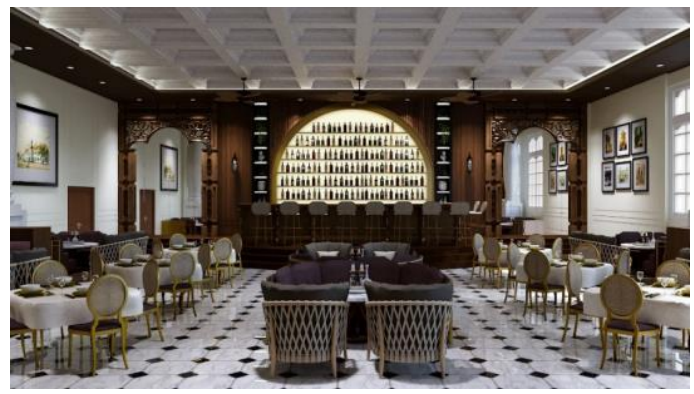

Gambar 2. Lounge \& Bar The Hermitage, A Tribute Portfolio Hotel, Jakarta (Sumber : Irvani,2020) 
Lounge \& Bar adalah sebuah tempat yang biasanya ada di hotel berbintang. Lounge \& Bar biasanya dijadikan tempat untuk minum-minum sambil bersantai dengan gaya yang lebih elegan. Lounge \& Bar yang biasanya terdapat di dalam hotel tempatnya luas dan memanjang. Ruangannya tertutup dan dilayani oleh bartender dan beberapa waiter.

Penjajahan Belanda pada kurun abad XVIII hingga abad XX tak hanya melahirkan kekerasan, tapi juga memicu proses pembentukan kebudayaan khas, yakni kebudayaan dan gaya hidup Indis. Budaya gado-gado, percampuran budaya Barat dan unsur-unsur budaya Timur. Ibarat darah, budaya campuran ini merasuk ke dalam segala perikehidupan manusia di masa itu, sebagaimana dituturkan oleh Prof. Dr. Djoko Soekiman dalam disertasinya, Kebudayaan Indis dan Gaya Hidup Masyarakat Pendukungnya di Jawa (1996), yang kemudian diterbitkan oleh Yayasan Bentang Budaya pada Januari 2000.

Pada Interior Lounge \& Bar The Hermitage, A tribute Portfolio, Jakarta diterapkan gaya Indis yang merupakan gaya kolonialisme yaitu perpaduan budaya Belanda dengan budaya Jawa. Ciri khas gaya Indis yang diterapkan pada Lounge \& Bar The Hermitage, A Tribute Portfolio, Jakarta adalah :

- Gaya Kolonial / Indis memiliki ciri yang menonjol yaitu mengekspos material yang ada, sehingga warna yang didapat adalah warna-warna natural, antara lain coklat kayu, merah bata, dan lain-lain. Ball (1117)

- Material untuk lantai biasanya lantai marmer. Ball (11-17)

- Material dari batu data atau kayu, biasanya di ekspos tanpa pelapis. Ball (11-17)

- Art and Craft

- Menggunakan konstruksi papan polos dan panel pintu pada masa Victorian yang menggunakan empat panel juga mendominasi gaya Art and Craft.

- Menggunakan konstruksi papan polos dan panel pintu pada masa Victorian yang menggunakan empat panel juga mendominasi gaya Art and Carft.

- Kaki meja biasanya berbentuk runcing, kayu padat, kaki octagonal berbentuk lengkung pada bagian depan (Kelly 76-86). 
Fakultas Seni Rupa dan Desain - Universitas Tarumanagara

Irvani Anwar, Stephanus Dwiyanto, Sri Sulistyo Purnomo; Halaman 40-49

- Perabot juga mengkombinasikan bentuk garis hotizontal dan vertical yang terlihat simpel dengan proporsi yang elegan (Turgeon 71)

\section{B. Elemen Pembentuk Ruang}

\section{LANTAI}

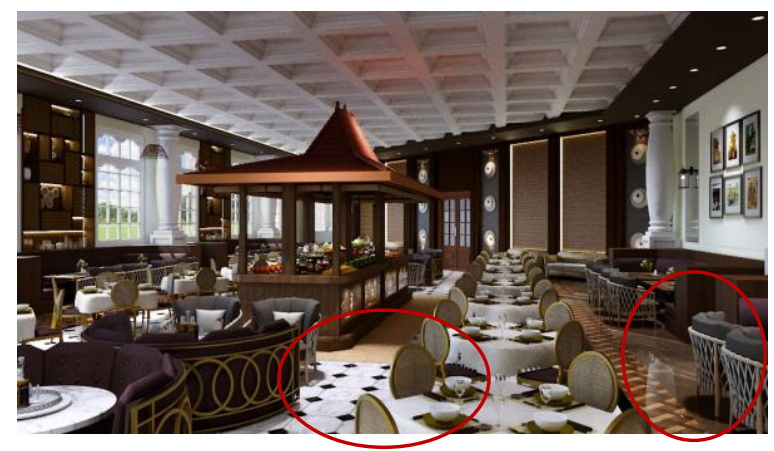

Gambar 3. Lantai Lounge \& Bar The Hermitage, A Tribute Portfolio Hotel, Jakarta

(Sumber : Irvani, 2020)

Lantai Lounge \& Bar menggunakan material granit motif geometric. Penggunaan material granit ini sesuai dengan pengaruh gaya Empire Style yang muncul sekitar tahun 1870-1900, di mana gaya ini dipelopori oleh Daendles. Penggunaan granit memberikan kesan menarik dengan tampilan megah dan elegan. Dari segi warna, warna yang digunakan pada lantai granit adalah kombinasi putih cream dan abu, dengan motif serat khas marmer serta warna hitam geometric. Pada bagian pinggir ruangan menggunakan granit dengan pola kayu berwarna coklat untuk menampilkan unsur tradisional.

\section{DINDING}

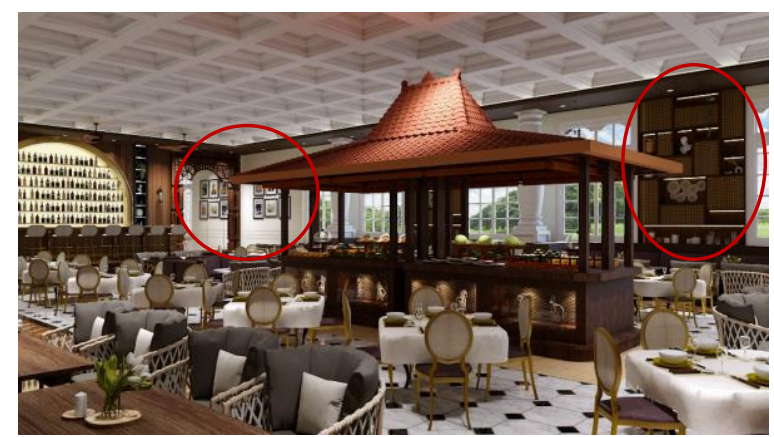

Gambar 4. Dinding Lounge \& Bar The Hermitage, A Tribute Portfolio Hotel, Jakarta (Sumber : Irvani, 2020)

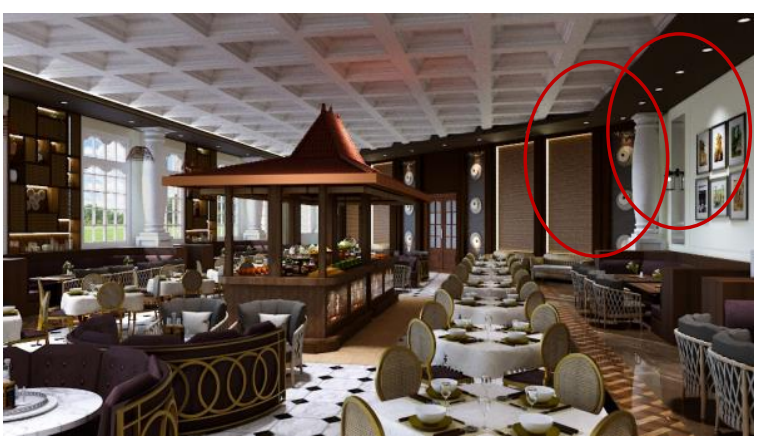

Gambar 5. Dinding Lounge \& Bar The Hermitage, A Tribute Portfolio Hotel, Jakarta (Sumber : Irvani, 2020)

Pada bagian dinding kiri dan kanan sisi Bar menggunakan wood panel classic berwarna coklat disertai dengan cermin gebyok jawa, pada dinding sebelah kanan ruangan menggunakan panel kayu dengan lemari display rotan di antara jendela untuk menampilkan unsur lokal Jawa, pada bagian dinding entrance Lounge $\&$ Bar juga menampilkan unsur jawa dengan penggunaan panel kayu yang dihiasi dengan ukiran floral khas jawa juga penggunaan dekorasi kayu berbentuk lingkaran. Sedangkan pada dinding bagian 
Fakultas Seni Rupa dan Desain - Universitas Tarumanagara

kiri menggunakan wallpanel gypsum dengan fisnishing wallpaint berwarna putih yang menampilkan unsur kolonial disertai dengan dekorasi foto pada saat era Kolonial Belanda.

\section{PLAFON}

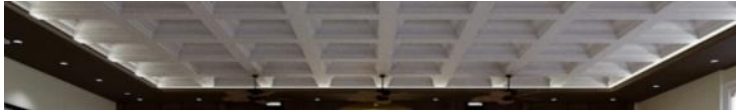

Gambar 6. Plafon Lounge \& Bar The Hermitage, A Tribute Portfolio Hotel, Jakarta (Sumber : Irvani, 2020)

Bagian plafon menggunakan gypsum dengan gaya classic belanda dengan finishing wallpaint berwarna putih, sedangkan pada bagian kiri dan kanan plafon terdapat downceiling menggunakan kayu berwarna coklat. Kedua perpaduan warna tersebut menampilkan kesan yang natural namun terlihat mewah.

\section{FURNITURE}

Furniture yang digunakan dominan custom dengan model classic yang dominan menggunakan material kayu serta adannya aksen penggunaan rotan.
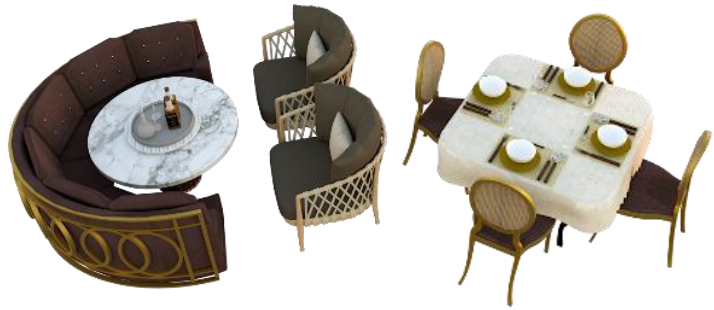

Gambar 7. Furniture Classic dan Rotan Lounge \& Bar The Hermitage, A Tribute Portfolio Hotel, Jakarta (Sumber : Irvani, 2020)
Pada (Gambar 7) terlihat furniture sofa Lounge \& Bar dominan menggunakan bentuk melengkung yang menampilkan kesan classic dengan perpaduan warna wine untuk menampikan kesan elegant dan hijau army yang merupakan warna aksen pada konsep perancangan ini, sedangkan warna gold besi pada bagian sofa dan kursi untuk menampilkan kesan kemewahan. Pada bagian kursi juga ada perpaduan rotan yang menampilkan citra tradisional sesuai dengan gaya Indis yang pada era tersebut penggunaan furniture dominan menggunakan kayu dan rotan.

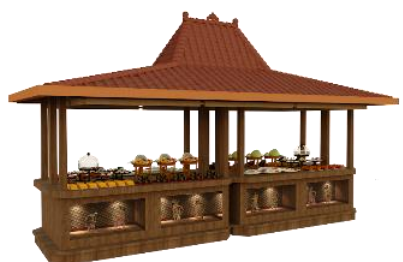

Gambar 8. Buffet Lounge \& Bar The Hermitage, A Tribute Portfolio Hotel, Jakarta (Sumber : Irvani, 2020)

Pada bagian buffet memiliki atap yang berbentuk atap rumah joglo, konsep ini diambil dikarenakan sesuai dengan gaya yang diangkat yaitu gaya Indis dimana pada era tersebut gaya arsitektur berpacu pada arsitektur Jawa salah satunya adalah gaya arsitektur rumah Joglo. Sedangkan pada area bawah terdapat dekorasi pewayangan dengan pencahayaan lampu sorot. 
- Analisa mengenai lantai, dinding dan plafond jelas.

\section{KESIMPULAN}

Dari hasil perancangan yang diteliti, dapat disimpulkan bahwa Tipologi Lounge \& Bar The Hermitage, A Tribute Portofolio Hotel, Jakarta ini sudah menerapkan gaya indis yang sesuai dengan karakteristik bangunan baik pola arsitektur maupun interior restoran beserta elemen dekorasi dan furnitur yang didukung elemen interior pembentuk ruang (lantai, dinding, plafond).

Hal-hal yang menjadi kekurangan dalam penelitian ini adalah :

- Tidak adanya dokumentasi pribadi dari peneliti

- Tidak dapat dilakukan penelitian lebih mendalam dengan observasi langsung ke lapangan mengenai pola arsitektur, elemen dekoratif, furnitur, elemen interior, yang terkait dengan warna, bentuk, corak dikarenakan adanya pademi Covid-19.

Hal-hal yang menjadi kelebihan dalam penelitian ini adalah :

- Adanya penjelasan baik dalam arsitektur maupun interior

V. DAFTAR PUSTAKA

Antariksa. 2010. Tipologi Wajah Bangunan dan Riasan dalam Arsitektur Kolonial Belanda. http://antariksaarticle.blogspot.co m/2010/05/tipologi-wajahbangunan-dan-riasan.html (diakses pada tanggal 18 Februari 2014)

Djoko Soekiman. 2011. Kebudayaan Indis Dari Zaman Kompeni Sampai Revolusi. Jakarta : Komunitas Bambu.

Yohannes Firzal. 2011. Tipologi Bangunan Tua. Local Wisdom Jurnal IImiah Online ISSN: 20863764. Volume: III, Nomor: 2, Halaman: $33-42$

Crochet, Treena. Colonial style : creating classic interiors in your cape, colonial, or saltbox home. Newtown, CT: The Taunton Press, Inc (2005) 
Fakultas Seni Rupa dan Desain - Universitas Tarumanagara

Irvani Anwar, Stephanus Dwiyanto, Sri Sulistyo Purnomo; Halaman 40-49

Kilmer, Rosemary, Designing Interior, John Wiley \& Sons, Inc., New Jersey, 2014

\section{WEBSITE}

- https://www.researchgate.net/pu blication/316668731 GAYA BANG UNAN ARSITEKTUR_KOLONIAL PA DA BANGUNAN UMUM BERSEJA RAH DI KOTA MANADO (diunduh pada tanggal 23 April 2020 ) 